\title{
The Worldwide Abalone Industry
}

\author{
Peter A. Cook \\ Center of Excellence in Natural Resource Management, The University of Western Australia, \\ Albany, Australia \\ Email: peter.cook@uwa.edu.au
}

Received 14 October 2014; revised 18 November 2014; accepted 3 December 2014

Copyright (C) 2014 by author and Scientific Research Publishing Inc.

This work is licensed under the Creative Commons Attribution International License (CC BY). http://creativecommons.org/licenses/by/4.0/

(c) (i) Open Access

\begin{abstract}
Global fish production continues to outpace world population growth, and aquaculture remains one of the fastest-growing food producing sectors. In 2012, global aquaculture production was 90.4 million tonnes. Although, in terms of production tonnage, abalone contributes a relatively small proportion of this aquaculture production, it is one of the most highly prized seafood delicacies and, therefore, in terms of the value of production, is very important to many countries. The total volume of worldwide abalone fisheries has declined since the 1970's, but farm production has increased significantly over the past few years. A huge increase in farm production has occurred, beginning in the 1970s, when farm production was almost negligible, to recent years when increases have been huge. In the 8 years immediately preceding 2010, for example, farm production increased by more than $750 \%$ and by 2013 , farm production had reached an estimated 103,464 mt. The overall effects of these huge increases on the world market are discussed.
\end{abstract}

\section{Keywords}

Abalone, Shellfish, Worldwide Market

\section{Introduction}

According to FAO statistics [1] global fish production continues to outpace world population growth, and aquaculture remains one of the fastest-growing food producing sectors. In 2012, aquaculture set another all-time production high and now provides almost half of all fish for human food. This share is projected to rise to 62 percent by 2030. In 2012, global aquaculture production was 90.4 million tonnes (live weight equivalent) worth an estimated US \$144.4 billion, and this included 66.6 million tonnes of food fish and 23.8 million tonnes of aquatic algae. China alone produced 43.5 million tonnes of food fish and 13.5 million tonnes of aquatic algae that year. Production for 2013 was estimated at 70.5 million and 26.1 million tonnes, respectively [1].

Although, in terms of production tonnage, abalone contributes a relatively small proportion of this aquacul- 
ture production, it is one of the most highly prized seafood delicacies in many parts of the world, particularly in Asia and, therefore, in terms of the value of production, is very important to many countries. Whilst the total volume of worldwide abalone fisheries has declined since the 1970's, farm production has increased significantly over the past few years. In order to understand the reasons for this, it is necessary to compare current trends in supply and demand with those of the "heyday” of world abalone fisheries, back in the 1970's [2]. In those days, there was little regulation of abalone fisheries, the illegal catch was insignificant, and total worldwide farm production totaled just a few metric tonnes.

For the purposes of this article, the following definitions will be used [3].

- Abalone Fisheries: The total (legal) allowable annual commercial catch. This category includes the planting of seeds in large areas of the sea wherein the sea bottom has not been prepared with man placed rocks or structures. This definition does not include the legal sport catch or any illegal catch worldwide.

- Cultured Abalone: Includes both the farming of abalone on land or in the sea, contained in man-made tanks, nets or structures (Intensive Culture), and the sea-planting of abalone seeds in artificially arranged substrate or structures, with or without added food (Extensive Culture).

- Illegal Catch: Any harvest of abalone beyond the total allowable annual fishing quotas.

The figures used in this paper have been quoted, where possible, from published FAO statistics [1] [4] [5], and other published literature [2] [6]-[11]. In some cases, where the most recent information is not available from the FAO statistics, figures are estimated from personal communications. In all cases, figures are adjusted to represent "in shell” weight.

\section{World Abalone Supply}

Legal landings from abalone fisheries (Table 1) have gradually decreased from almost 20,000 metric tonnes (mt) in the 1970's to less than $8000 \mathrm{mt}$ in 2013 [10]. During this time, two of the world's major abalone fisheries (USA and South Africa) were de-commercialized [6] [12] [13], and whilst much of the USA fishery still remains closed [8], the South African fishery has recently been re-opened to a small (150 mt), experimental quota. Explanations for the decline include over-exploitation, illegal harvesting, disease and habitat degradation. The abalone fishery in Australia also declined over the past few years but, in this case, the decline was due to the outbreak of a serious abalone disease in both farmed and wild stocks [9].

At the same time as landings from legal fisheries were declining, farm production was rapidly increasing in several countries. Table 1 shows a huge increase in farm production, beginning in the 1970s, when farm production was almost negligible, to recent years when increases have been huge [10]. In the 8 years immediately preceding 2010, for example, farm production increased by more than $750 \%$ culminating, in 2010 , in an estimated worldwide output of 65,344 mt. Between 2010 and 2013, farm production increased by another 158\%, to reach an estimated 103,464 $\mathrm{mt}$ [14] [15].

The other major factor that has affected the world abalone market, over the past decade or so, has been a huge increase in illegal catches. It has been suggested [10] that in 2008, the worldwide illegal catch totaled about 5 $300 \mathrm{mt}$, this representing over $65 \%$ of the total legal catch from fisheries (7869 mt). In the years since 2008, there is some evidence that increased efforts to reduce poaching in countries such as South Africa and Australia, has resulted in slightly less illegal product reaching the market [10]. Most of the illegal abalone catch is sold into

Table 1. Total global production of abalone from legal fisheries and from farms.

\begin{tabular}{cccc}
\hline Year & Fishery production & Farm production \\
1970 & 19,720 & 50 \\
1989 & 14,830 & 1200 \\
2002 & 10,146 & 8700 \\
2008 & 7869 & 30,760 \\
2010 & 7424 & 65,344 \\
2011 & 7424 & 85,344 \\
2013 & 7486 & 103,464
\end{tabular}


Asia, and illegal channels through Hong Kong are common. There is no doubt that the availability of about 5000 $\mathrm{mt}$ of illegal catch has had, and continues to have, a seriously destabilizing effect on the world market.

From the above figures, it can be estimated that the total supply of abalone to the world market, from all sources, (fisheries, cultured and illegal catch) was 20,370 mt in 1970, 22,667 mt in 2002, 44,510 mt in 2008, 73,206 $\mathrm{mt}$ in 2010, and 115,692 $\mathrm{mt}$ in 2013. Thus, in 2013, the total supply was more than three times that available in what has been considered the "heyday" of world abalone supply during the 1970's. This impressive return to substantial supplies, in which the illegal catch plays no small role is, of course, due mainly to the huge increase in farmed abalone from China where estimated farm production for 2013 to 2014 was 90,694 mt [14]. A significant increase in farm production has also occurred in Korea [11] [15] and in Chile [16]. Although, as indicated in information published by the FAO, there are many constraints to the further development of abalone aquaculture such as feed availability [17], there is reason to believe that farm production will continue to increase, particularly after the current downturn in world economies has turned around [5] [18]. Table 2 lists farm production of abalone in 2010, 2013-2104 and estimates 2015 production.

In China there were over 300 operating abalone farms in 2013, with the largest individual farm producing: over $1000 \mathrm{mt}$ per year [14]. Some of the newer Chinese farms are amongst the most efficient in the world. In 2004, about $60 \%$ of abalone farms in China were land-based, but by 2010 this had changed significantly with more than $95 \%$ of all farms being sea-based. In the sea-based farms, abalone are housed in various types of rearing cages, suspended form long-lines. The abalone are generally fed a mixture of seaweeds, with some farms now favouring artificial feeds as the preferred diet. A major disadvantage of sea-based farms is that they are subject to bio-fouling that requires regular cleaning of cages. Even taking this into account, however, abalone in sea cages can be grown to market size at much lower costs than in the land-based farms.

The bulk of Chinese abalone production is in the southern Provinces of Fujian and Guangdong. Much of the seed production is near Dalian in the Northern Province of Liaoning. The large increase in Chinese farm production has been accompanied by a change in the predominant species available on the world market. Back in 2004, Fujian Province accounted for over $60 \%$ of all abalone produced and sold in China, and a significant proportion of the Fujian total was the lower value species, $H$. diversicolorsupertexta, which generally sold for less than US $\$ 20 / \mathrm{Kg}$. By 2010 this situation had changed so that almost $95 \%$ of production was of the higher value species, either $H$. discushanni or a hybrid between $H$. discushanni and $H$. discus discus. This change was probably brought about because $H$. discushanni is the preferred species in Japan, and China is now exporting part of its production to Japan. Prices paid for Chinese abalone vary according to the species produced, with the Japanese abalone, $H$. discushanni, being the most valuable. Size also influences value with larger sizes commanding higher prices-

Table 2. Farm production (mt) in various regions in 2010, 2012-2013 and 2015 (estimated).

\begin{tabular}{|c|c|c|c|}
\hline Region & 2010 & 2013-2014 & 2015 (Estimated) \\
\hline China & 56,511 & 90,694 & 50,000 \\
\hline Korea & 6228 & 9300 & 10,000 \\
\hline South Africa & 1015 & 1116 & 1450 \\
\hline Chile & 794 & 794 & 700 \\
\hline Australia & 456 & 910 & 965 \\
\hline USA & 250 & 250 & 250 \\
\hline Japan (Seed Production) & 200 & 200 & 200 \\
\hline Taiwan & 171 & 171 & 171 \\
\hline New Zealand & 80 & 90 & 100 \\
\hline Mexico & 33 & 35 & 35 \\
\hline Europe & 30 & 100 & 120 \\
\hline Thailand & 10 & 15 & 18 \\
\hline Philippines & 4 & 8 & 10 \\
\hline
\end{tabular}


per Kg. When the predominant size sold in the market was 16/20 individuals per Kg, the price was relatively low but larger sizes are now beginning to appear in the Chinese market. For example, $H$. laevigata, from Australia, is sometimes available at about US $\$ 30 / \mathrm{Kg}$, but this product may be imported illegally [14].

Although it was expected that Chinese farm production would continue to increase, current information suggests that this is not occurring. Outbreaks of disease have slowed the rate at which production increases have occurred [19], and price drops during the Global Financial Crisis, have further depressed confidence in abalone farming. For example, plans by a major Chinese production group to raise up to RMB 1.3 billion (USD 209 million, EUR 154 million) in a private placement of abalone farm shares are being made more challenging by a heavy debt burden worrying potential investors. One of China's best-known seafood players, and a key shellfish producer, is dangerously over-leveraged, according to Chinese financial analysts.

Because of low prices and high mortality, more and more farmers have no confidence to culture abalone [14]. The number of abalone seed produced in 2013 was only about half of that in 2012 and, therefore, grow-out production in 2015 will reduce to about half of the 2013 production. The extent to which this will affect the world market is, as yet, unknown.

Korea is now a major supplier of abalone to the world market. Farm production, which is estimated to have increased by over 60 times over the past 10 years, totaled about $4500 \mathrm{mt}$ in 2007, $6288 \mathrm{mt}$ in 2010, and is estimated to reach over 10,000 mt by 2015 [15]. The majority of Korean production is in remote Wando County in South Jeolla Province, and about $85 \%$ of that production is exported to Japan. This production has had an important influence on the world market, particularly because the majority of the production is $H$. discushannai, the species that is most popular, and commands the highest price, in the Japanese market. Most individual Korean farms are, however, still relatively small scale producers. Distribution processes are now being developed on a national scale and production control, has been implemented to halt the decline in prices that was experienced as a result of the speed that the industry developed. Future developments in the Korean industry are likely to include a more coordinated production and marketing system.

In comparison to Asia, abalone farming in Europe is a very small, but growing, industry. Farms are located in the UK, the Channel Islands, Ireland, France and Spain [20]. In the UK, a small number of farms are located on the south coast of England, but these are mainly at the experimental level and production is currently insignificant. In Ireland farms are also mainly experimental, producing mostly H. discushanni, but it seems unlikely that production will exceed about $3 \mathrm{mt}$ in the near future, whilst in the Channel Islands there are two farming companies, currently producing less than one metric tonne. French farms are located in Brittany and Vendee, and these have the advantage of being located in regions where small, natural populations of abalone occur and have been fished for some years. Farm production from the French farms is likely to increase significantly over the next few years. The abalone farms that are developing in Spain plan to be producing about $30 \mathrm{mt}$ per year in about three years time.

Significant quantities of farmed abalone are produced in Chile, Japan, South Africa, Australia, Taiwan, New Zealand, Mexico, Thailand and the Philippines and, in all of those cases, it seems likely that production will increase in the future [2] [6]-[10]. In the USA, although about $250 \mathrm{mt}$ of abalone are produced each year, it seems likely that any future development of the industry along the Californian coast will be limited by land values and the costs of complying with environmental regulations [8] [12].

\section{World Abalone Market Trends}

The rest of the abalone-producing world has often seen China as a huge marketing opportunity that would, hopefully, increase demand and, therefore, prices. As China began to increase its own abalone production, however, the less optimistic marketers feared that over-production in China may, on the contrary, swamp world markets and depress prices. Experience to date has suggested that neither of these alternatives has really come about. This is because, although abalone consumption in China has definitely increased, to a large extent farm production within China has been increased to cope with this increased demand [21]. The overall influence of China on the world abalone market, and world abalone prices outside of China has, therefore, been less than some may have expected. Other factors have, however, produced instability in the world abalone market and have led to significant price fluctuations.

Between about 2008 and 2010 a combination of factors combined to depress world abalone prices. Some developed countries, e.g. the United States of America, have reduced their aquaculture output in recent years, 
mainly owing to competition from countries with lower production costs [1]. With respect to the world abalone market, in addition to increased world farm production, another important factor has been a greater availability of illegal product, that has increased world abalone supply to unprecedented levels. At the same time, the global financial crisis depressed demand for high-priced fisheries products, including abalone and, overall, during this period, prices were significantly reduced, sometimes by as much as 30\% [2]. Abalone has been particularly hard hit because the vast majority of abalone is sold into a very few Asian nations, mainly in traditional forms with no value-adding. Lack of product and customer diversification meant that farms were unable to move into alternative markets at times of market crisis, and several farms ceased operation during that time. Fortunately, the most recent information suggests that the worst is now over and world abalone prices are beginning to move in a positive direction.

\section{Conclusions}

The trends reported in this paper could have important implications for the future of the world abalone market. Total abalone production, around the world, seems unlikely to increase in the near future. Fisheries are almost all completely exploited, or even over-fished, and although some countries, such as Canada, are attempting to rebuild stocks, it seems unlikely that fisheries and ever be restored to former levels [22]. In addition, farming is unlikely to increase significantly in the current world financial situation. Demand for abalone in China, the world's biggest consumer of the product, has significantly decreased over the past couple of years and this has resulted in a general fall in prices. Similarly, in Japan, the recent downturn in the national economy has resulted in a decreased demand for luxury foods. Combined with austerity measures introduced recently in China, the overall global demand for abalone has dipped for the first time in many years. Until the economies of China and Japan begin to improve, it seems unlikely that worldwide demand for abalone will increase. It is, of course, notoriously difficult to predict trends in Asian economies, but there is no doubt that such trends will significantly affect demand and prices of abalone, throughout the world.

Although statistics published by the FAO suggest that the rate of increase of global aquaculture production slowed during the global financial crisis, there is reason to believe that the situation will revert to normal as the impact of the GFC lessens [5]. It is interesting to note the different effects that the GFC has had on abalone production in different parts of the world. Generally, the counties that have been most negatively affected are those that have high production costs, particularly labour costs. Countries such as the USA, Australia, New Zealand and those in Europe, have found it difficult to increase, or even maintain, production levels. Countries such as China, Korea and South Africa, that have relatively lower production costs, have also been negatively affected by the GFC, but may be able to recover more quickly once the GFC begins to abate. To be successful in the future, abalone farms will need to reduce production costs and improve profitability by, for example, implementing improved systems that use less water, less labour and more efficient feeding. Co-operation, co-ops, and joint marketing efforts could be used to reduce marketing costs. Additionally, farms could explore both product and customer diversification. Farms might also consider some type of international certification to set quality standards that may improve market access.

\section{References}

[1] FAO (2014) The State of World Fisheries and Aquaculture: Opportunities and Challenges. Food and Agriculture Organisation of the United Nations. FAO, Rome.

[2] Cook, P.A. and Gordon, G.H. (2010) World Abalone Supply, Markets and Pricing. Journal of Shellfish Research, 29, 569-571. http://dx.doi.org/10.2983/035.029.0303

[3] Gordon, H.R. and Cook, P.A. (2004) World Abalone Fisheries and Aquaculture Update: Supply and Market Dynamics. Journal of Shellfish Research, 23, 935-939.

[4] FAO (2008) FAO Yearbook, 2008; B-52 Abalones, Winkles, Conchs. FAO, Rome.

[5] FAO (2010) Fisheries and Aquaculture Topics. The State of World Fisheries and Aquaculture (SOFIA). Topics Fact Sheets. In: FAO Fisheries and Aquaculture Department, Rome. (Online) http://www.fao.org/fishery/sofia/en

[6] Korpov, K.A., Haaker, P.L., Taniguchi, I.K. and Rogers-Bennett, L. (2000) Serial Depletion and Collapse of the Californian Abalone (Haliotis spp.) Fishery. Canadian Special Publication on Fisheries and Aquatic Science, 130, 11-24.

[7] Searcy-Bernal, R., Ramade-Villanueva, M.R. and Altamira, B. (2010) Current Status of Abalone Fisheries and Culture 
in Mexico. Journal of Shellfish Research, 29, 573-576. http://dx.doi.org/10.2983/035.029.0304

[8] Neuman, M., Tissot, B. and Vanblaricom, G. (2010) Overall Status and Threats Assessment of Black Abalone (Haliotiscracherodii Leach, 1814) Populations in California. Journal of Shellfish Research, 29, 577-586. http://dx.doi.org/10.2983/035.029.0305

[9] Mayfield, S., McGarvey, R., Gorfine, H.K., Peters, H., Burch, P. and Sharma, S. (2011) Survey Estimates of Fishable Biomass Following a Mass Mortality in an Australian Molluscan Fishery. Journal of Fish Diseases, 34, $287-302$. http://dx.doi.org/10.1111/j.1365-2761.2011.01241.x

[10] Gordon, H.R. and Cook, P.A. (2013) World Abalone Supply, Markets and Pricing: 2011 Update. Journal of Shellfish Research, 32, 5-7. http://dx.doi.org/10.2983/35.032.0102

[11] Park, C.-J. and Kim, S.Y. (2013) Abalone Aquaculture in Korea. Journal of Shellfish Research, 32, 17-20. http://dx.doi.org/10.2983/035.032.0104

[12] Kashiwada, J.V. and Taniguchi, I. (2007). Application of Recent Red Abalone (Haliotis rufescens) Surveys to Management Decisions Outlined in the California Abalone Recovery and Management Plan. Journal of Shellfish Research, 26, 713-718. http://dx.doi.org/10.2983/0730-8000(2007)26[713:AORRAH]2.0.CO;2

[13] California Department of Fish and Game (2009) http://www.dfg.ca.gov/marine

[14] You, W.W. (2014) Pers. Comm.

[15] Park, C. (2014) Pers. Comm.

[16] Flores-Aguilar, R.A., Gutierrez, A., Ellwagner, A. and Searcy-Bernal, R. (2007) Development and Current Status of Abalone Aquaculture in Chile. Journal of Shellfish Research, 26, 705-711. http://dx.doi.org/10.2983/0730-8000(2007)26[705:DACSOA]2.0.CO;2

[17] Klinkhardt, M. (2007) The Blue Revolution—Feed Alternatives for Aquaculture. In: Arthur, R. and Nierentz, J., Eds., Global Trade Conference on Aquaculture, Qingdao, 29-31 May 2007, 261-267.

[18] Fishtech (2012) http://www.fishtech.com

[19] Zhang, G., Que, H., Liu, N. and Xu, H. (2004) Abalone Mariculture in China. Journal of Shellfish Research, 23, 947950.

[20] Cook, P.A. (2010) Developments and Trends in Worldwide Abalone Farming and Implications for the European Industry. Aquaculture Europe, 30, 5-8.

[21] Nie, Z. and Wang, S. (2004) The Status of Abalone Culture in China. Journal of Shellfish Research, 23, 941-945.

[22] Lessard, J. and Campbell, A. (2007) Describing Northern Abalone, Haliotiskamtschatkana, Habitat: Focusing Rebuilding Efforts in British Columbia, Canada. Journal of Shellfish Research, 26, 677-686. http://dx.doi.org/10.2983/0730-8000(2007)26[677:DNAHKH]2.0.CO;2 
Scientific Research Publishing (SCIRP) is one of the largest Open Access journal publishers. It is currently publishing more than 200 open access, online, peer-reviewed journals covering a wide range of academic disciplines. SCIRP serves the worldwide academic communities and contributes to the progress and application of science with its publication.

Other selected journals from SCIRP are listed as below. Submit your manuscript to us via either submit@scirp.org or Online Submission Portal.
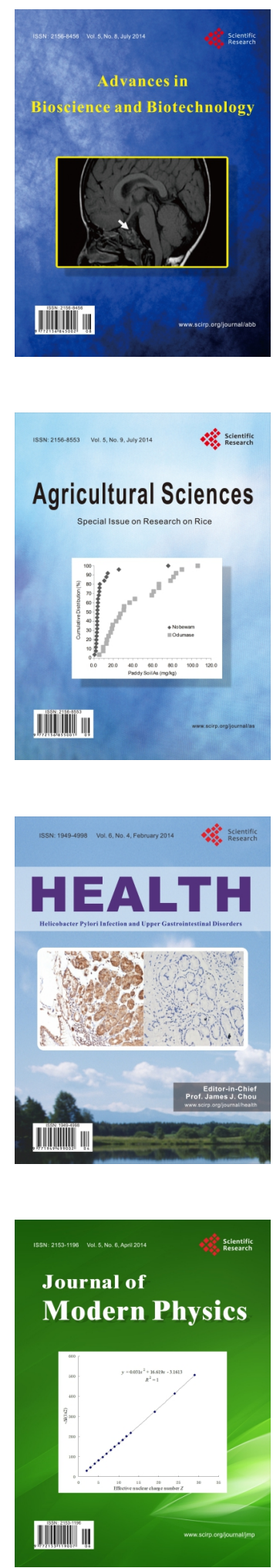
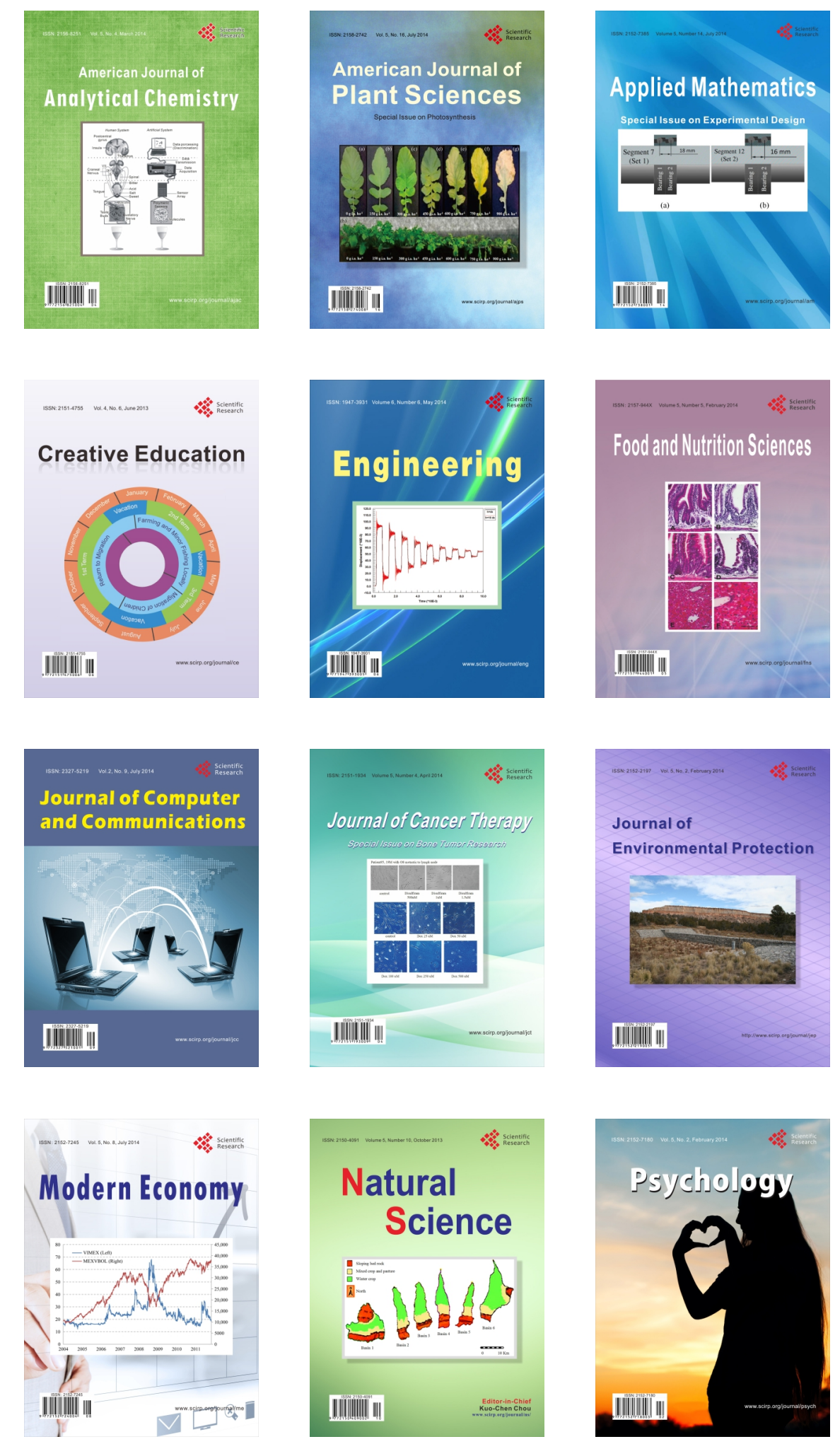